\title{
Radical gastric cancer surgery results in widespread up- regulation of pro-tumourigenic intraperitoneal cytokines
}

Andrew J. LONG ${ }^{1}$, Paul R. BURTON ${ }^{1}$, Michael J. DE VEER ${ }^{3}$, Geraldine J. OOI ${ }^{1}$, Cheryl P. LAURIE $^{1}$, Peter D. NOTTLE ${ }^{2}$, Matthew J. WATT ${ }^{3}$, and Wendy A. BROWN ${ }^{1}$

${ }^{1}$ Centre for Obesity Research and Education, Monash University, Melbourne 3004, AUSTRALIA

${ }^{2}$ Department of Upper Gastro-Intestinal Surgery, The Alfred Hospital, 55 Commercial Rd, Melbourne 3004, AUSTRALIA;

${ }^{3}$ Department of Physiology, Monash University, Melbourne 3800, AUSTRALIA

Corresponding author and person to whom reprint requests should be addressed: Geraldine J Ooi

Centre for Obesity Research and Education, Monash University, Phone: +61411113673/+61399030725

This is the author manuscript accepted for publication and has undergone full peer review but has not been through the copyediting, typesetting, pagination and proofreading process, which may lead to differences between this version and the Version of Record. Please cite this article as doi: $10.1111 /$ ans.14267

This article is protected by copyright. All rights reserved. 
Fax: +61399030717

Email: geraldine.ooi@monash.edu

\begin{abstract}
Running head: Pro-tumourigenic cytokines during gastric surgery
\end{abstract}
Word count: 2938 (excluding tables and figures)

This manuscript contains five figures and one table, with supplementary material attached.

\title{
Disclosure statement:
}

The Centre for Obesity Research and Education has received funding for research purposes from Allergan, Inc. and Apollo Endosurgery, the manufacturer of the LAP-BAND and for educational purposes from Applied Medical. Prof Brown reports financial support for a bariatric surgery registry from the Commonwealth of Australia, Apollo Endosurgery, Covidien, Johnson and Johnson, Gore and Applied Medical. Dr Ooi reports scholarships from the National Health and Medical Research Council and the Royal Australasian College of Surgeons. Prof Watt is a Senior Research Fellow of the National Health and Medical Research Council of Australia. The remaining authors have no disclosures or conflicts of interest.

This article is protected by copyright. All rights reserved. 
Presented at Asia-Pacific Gastroesophageal Cancer Congress meeting, Brisbane Convention and Exhibition Centre, 16 to 18 March, 2015

Keywords: oesophageal neoplasms, stomach neoplasms, immune cells, neoplasm recurrence, inflammation, cytokines, adipose tissue

\begin{abstract}
Abbreviations:
OG - oesophago-gastric; IL - interleukin; TNF - tumour necrosis factor; PCR - polymerase chain reaction; CCL2 - chemokine C-C motif ligand 2; SEM - standard error of the mean; qRT-PCR - quantitative real time polymerase chain reaction; ICU - intensive care unit; mRNA - messenger ribosomal nucleic acid; NK-cells - natural killer cells;
\end{abstract}

This article is protected by copyright. All rights reserved. 


\section{ABSTRACT}

Background: Radical surgical resection is the mainstay of curative treatment for oesophagogastric (OG) malignancy. However, survival and recurrence rates remain poor. Theoretical data suggests that the inflammatory response to surgery can promote tumour recurrence. The local and systemic inflammatory response to radical OG cancer surgery has not been fully characterized. We aimed to measure this response, particularly factors associated with tumour implantation.

Methods: Consecutive patients undergoing radical junctional or gastric cancer resection over twelve months were recruited. Repeated serum and adipose tissue were collected intraoperatively. Adipose tissue was collected adjacent and remote to the tumour, and cytokine mRNA expression was measured. Post-operatively, daily serum was collected for seven days, and analysed for inflammatory cell profile and cytokine concentration.

Results: There were nine patients recruited (67.1 \pm 2.1 years). mRNA expression of IL-6, CCL2 and IL- $1^{2}$ increased in adipose tissue intra-operatively $(\mathrm{p}<0.05)$, equally both adjacent and remote from the tumour site. Serum IL-6 concentration increased from $23.3 \mathrm{pg} / \mathrm{mL}$ to $161.8 \mathrm{pg} / \mathrm{mL}$ intra-operatively $(\mathrm{p}<0.05$ ) before falling steadily to $35.7 \mathrm{pg} / \mathrm{mL}$ post-operatively $(p<0.05)$. Serum TNF- \pm was elevated throughout, and IL- $1^{2}$ levels were unaffected. Leukocyte and neutrophil populations increased, while T-cell and dendritic cell populations decreased intra-operatively $(\mathrm{p}<0.05)$. 
Conclusion: Radical surgery dramatically up-regulates the expression of pro-tumourigenic cytokines in the peritoneum. There is also a marked systemic immune and inflammatory response to surgery, including down-regulation of T-cell and dendritic cell populations. This offers two potential pathways that may facilitate tumour progression - local inflammation promoting peritoneal adherence and implantation, and secondary suppression of immunosurveillance due to circulating inflammatory response.

Abstract word count: 250

This article is protected by copyright. All rights reserved. 


\section{Introduction}

Surgical resection remains the mainstay of curative treatment for gastric and oesophago-gastric (OG) junctional carcinoma. Oncologic surgical resection is recommended to maximize the probability of complete tumour clearance, improve long-term survival and reduce loco-regional recurrence. However, recurrence rates post-operatively are high even after radical resectional surgery with curative intent. ${ }^{1}$ A possible contributing factor to this could be the increased inflammatory reaction induced by surgical trauma as a potential mediator of worsened outcomes.

The systemic inflammatory response to surgical trauma has previously been described. ${ }^{2,3}$ Its role relating to the immediate post-operative course and susceptibility to post-operative infections has been well characterised. ${ }^{2}$ Intraoperatively, an exaggerated local and systemic acute phase response occurs, resulting in profound immunological dysfunction. ${ }^{3}$

The causative link between inflammation and cancer has long been suspected. Inflammation plays a central role in the immune system's response to combat cancer, ${ }^{4,5}$ but paradoxically it is also a vital causative component in initiation, promotion and progression of a tumour. ${ }^{6,7}$ There is now substantial evidence supporting the role of systemic and infective inflammation in promotion of carcinogenesis, as well as poorer oncological outcome. ${ }^{4,6-8}$ Numerous laboratory and animal models have demonstrated the propensity for pro-inflammatory cytokines to promote endothelial adhesion of colorectal, lung, gastric and ovarian cancer cells. ${ }^{9-11}$ 
There are some key cytokines that demonstrate properties that could lead to tumour implantation and dissemination. Interleukin-1 (IL-1 and IL-6), tumour necrosis factor- \pm (TNF- \pm ) and CC-chemokine ligand-2 (CCL-2) play a major role in inflammation, tumour sustainability and progression. ${ }^{6}$ The IL- 1 family of cytokines, including IL- $1 \pm$ and IL- $1^{2}$, perpetuates inflammation by inducing the expression of many pro-inflammatory genes. ${ }^{12,13}$ $\mathrm{TNF}- \pm$ is produced by macrophages and T-cells, and plays a critical role in the maintenance and homeostasis of the physiologic immune system. ${ }^{14}$ Both TNF- \pm and IL- 6 promote progression of tumour cells via activation of the nuclear transcription factor ${ }^{\circ} \mathrm{B}\left(\mathrm{NF}^{-} \mathrm{B}\right)$ and other proliferative factors. ${ }^{14,15}$ Overall, up-regulation in these factors are linked to increased angiogenesis, inflammatory cell infiltration, and tumour invasiveness. ${ }^{12,16}$

Oesophagogastric (OG) cancer resections involve extensive and often prolonged surgery. There are few data in humans describing the pro-tumourigenic local and systemic inflammatory response specific to this surgery. In particular, the intra-peritoneal inflammatory reaction has not been previously described. Investigating this reaction may help to better understand a potential mechanisms that facilitates tumour implantation, dissemination and early recurrence.

In this study, we aimed to establish potential immune and inflammatory markers that were altered during the course of surgery, which have been linked to the promotion of tumour implantation and dissemination on a basic science level. We aimed to explore these markers in intra-peritoneal tissues, both adjacent and remote to the site of surgery, as well as serum during and after surgery. 
We hypothesized that radical OG cancer surgery would induce a profound and prolonged local and systemic inflammatory response. We hypothesized that this response would globally affect intraperitoneal tissue and not be confined to the operative site.

This article is protected by copyright. All rights reserved. 


\section{Methods}

This study was conducted in accordance with the National Statement on Ethical Conduct in Human Research and received approval from Alfred Health Human Ethics Committee (82/14) and Cabrini Human Research Ethics Committee.

\section{Study population}

Consecutive patients diagnosed with oesophago-gastric junctional or gastric malignancy undergoing curative surgical resection, involving radical upper abdominal lymphadenectomy (equivalent to modified Western D2 gastrectomy) between July 2014 and September 2014 were recruited. Patients were excluded if there was pre-operative evidence of metastasis or a history of previous malignancy. Clinical data were collected, including demographics, treatment details, operative details, estimated blood loss, peri-operative complications and morbidity.

\section{Surgical technique}

Patients underwent a standard en-bloc radical gastrectomy or oesophagectomy. Quality control related to ensuring an adequate lymph node yield had been achieved. ${ }^{17}$ Figure 1 is an overview of the tissue sample collection and biochemical analysis for each patient recruited.

This article is protected by copyright. All rights reserved. 


\section{Serum samples}

Intra-operatively, peripheral blood was collected from an arterial line immediately prior to initial incision, two hours after initial incision and immediately prior to peritoneal closure. Peripheral blood was also collected daily for seven days post-operatively for cytokine analysis.

\section{Adipose tissue samples}

Peri-visceral adipose tissue was removed from the closest available point to the visible tumour mass and at a distant intra-peritoneal point not involved with the primary tumour site (mesocolic fat). Samples were collected from these regions at the commencement of surgery, two hours after initial incision and immediately prior to peritoneal closure. All samples were snap frozen in dry ice and stored in a $-80^{\circ} \mathrm{C}$ freezer.

\section{Tissue analysis}

Inflammatory markers with known associations with tumour dissemination and implantation at a basic science level were selected for analysis.

\section{Determination of serum cytokines}

All intra-operative and post-operative serum samples underwent ELISA to quantify concentrations of IL-6, IL-1 ${ }^{2}$, CCL2 and TNF- \pm (Invitrogen, Maryland, USA) (details in

\section{Supplementary Material).}

This article is protected by copyright. All rights reserved. 


\section{Determination of inflammatory cell profile}

Total leukocyte and leukocyte subset concentrations in peripheral blood intraoperatively were determined with a flow cytometer. Populations of neutrophils, eosinophils, dendritic cells (DC), monocytes, plasmacytoid dendritic cells (pDC), B-cells, T-cells, NKcells and total lymphocytes were gated in samples stained with antibody mix and counted. Full details of flow cytometry are provided in the Supplementary Materials.

\section{Determination of pro-inflammatory cytokine $\mathrm{mRNA}$ expression}

Quantitative real-time PCR was performed on adipose tissue samples to determine mRNA expression of IL-6, IL-1 $\beta$, TNF- $\alpha$ and CCL2. Further details of tissue analysis methods are provided in the Supplementary Materials.

\section{Statistics}

GraphPad PRISM (Version 6.0, GraphPad Software Inc., California, USA) and IBM SPSS Statistics (Version 22.0, IBM Corp., New York, USA) software were used. All data were tested for normality using Kolmogorov-Smirnov test. Demographic data are expressed as mean \pm standard error of the mean (SEM).

qRT-PCR data were analysed with two-way analysis of variance and mean cytokine concentrations were analysed with one-way analysis of variance, followed by multiple comparisons using Bonferroni post hoc tests to identify significant differences. Flow cytometry data of inflammatory cell populations are expressed as mean \pm standard error of the mean (SEM). Mean difference in cell populations was assessed with paired t-tests and cell 
subpopulation ratios were analysed with chi-square tests. $\mathrm{p}<0.05$ was considered statistically significant.

This article is protected by copyright. All rights reserved. 


\section{Results}

\section{Demographics}

Nine patients undergoing transabdominal resectional surgery for OG malignancy with curative intent were recruited. Demographic information, relevant pre-operative clinical data and operative details are summarised in Table 1. No complications of grade II or higher were observed according to Clavien-Dindo classification.

\section{Intraoperative adipose tissue cytokine mRNA expression}

IL-6 (Figure 2A) and CCL2 (Figure 2B) mRNA expression was significantly increased from baseline at the " 2 hour" and "End" $(p<0.001)$. There was a significant elevation of IL- $1^{2}$ mRNA expression by the End $(\mathrm{p}=0.002)$ (Figure 2C). This response was similar in tissue collected adjacent to and remote from the surgical site. No change in TNF- $\alpha$ was observed.

\section{Intra-operative serum inflammatory cell profile}

A significant increase in mean serum total leukocyte concentration was seen from baseline to end of surgery (1198 cells $/ \mu \mathrm{L}$ to 2059 cells $/ \mu \mathrm{L}, \mathrm{p}=0.05)$ (Figure 3A).

\section{Myeloid cell profile}

There was a significant increase in neutrophil concentration $(\mathrm{p}=0.05)$ and a significant decrease in dendritic cell concentration ( $\mathrm{p}=0.01$ ) intra-operatively (Figure 3B and C). No

This article is protected by copyright. All rights reserved. 
statistically significant differences in any other myeloid populations were seen (monocytes, $\mathrm{p}=0.18$; plasmacytoid dendritic cells, $\mathrm{p}=0.10$; and eosinophils, $\mathrm{p}=0.18$ ).

\section{Lymphoid cell profile}

A significant decrease in total T-cell concentration $(\mathrm{p}=0.05)$ was observed (Figure 3D). When sorted by four subpopulations of T-cells (CD4 and CD8 surface markers), all Tcell subpopulations decreased, although these changes were not statistically significant (Table S3). There was no statistically significant difference observed in any other lymphoid cell line (B-cells, $p=0.16$; and NK-cells, $p=0.32$ ) measured across the intra-operative period (Figure S1).

\section{Intra-operative serum cytokines concentrations}

Serum IL-6 levels were increased from baseline to the " 2 hour" time point in all nine patients, peaking at the "End" time point for eight of the nine patients $(23.3 \mathrm{vs} 161.8 \mathrm{pg} / \mathrm{mL}$, $\mathrm{p}=0.02)$ (Figure 4A). There was pronounced variability in the increase in IL-6 concentration intra-operatively (range: $9.9-350.0 \mathrm{pg} / \mathrm{mL}$ ). There was no statistically significant change in TNF- \pm concentrations intra-operatively $(\mathrm{p}=0.92)$, which was elevated at the start of the case and remained elevated throughout surgery in all patients (Figure 4B). IL-1 ${ }^{2}$ concentration was low throughout, with no significant change intraoperatively (Figure 4C).

\section{Serum cytokine concentrations post-operatively}

The mean IL-6 concentration steadily fell in the week following surgery and was marginally higher than baseline levels by day six (161.8 vs 35.7pg/mL, p=0.04) (Figure 4A). 
Serum $\mathrm{TNF}- \pm$ concentration was maintained post-operatively throughout the peri-operative period with no statistically significant change (Figure 4B). There was no statistically significant difference of IL- $1^{2}$ concentration between any time points (Figure 4C).

This article is protected by copyright. All rights reserved. 


\section{Discussion}

This study describes the local and systemic inflammatory response to radical surgery for OG cancer. It showed significant inflammatory reaction to surgical resection, particularly the up-regulation of pro-tumourigenic markers. Our principal finding was that the intraoperative mRNA expression of inflammatory cytokines in adipose tissue increased substantially in intraperitoneal visceral adipose tissue. This occurred throughout the peritoneum, including peritoneal tissues remote to the operative site. Additionally, systemic post-operative cytokine and immune cell inflammatory response was one that demonstrated features adverse to tumour immunosurveillance, with universally decreased T-cell populations.

We were not surprised to observe an increase in inflammation in the adipose tissues adjacent to the operative site. Unexpectedly, however, an identical elevated inflammatory response was observed remote to the tumour and operative site. The markers that significantly increased intra-operatively throughout the peritoneal cavity were IL-1 ${ }^{2}$, IL-6 and CCL2 mRNA, which are implicated in facilitating local endothelial tumour cell adhesion, growth and metastases. ${ }^{6,10,18,19}$ This complements findings of previous studies that have reported evidence of overall peritoneal inflammation after resectional surgery, via increased IL-6 in post-operative drain tube fluid. ${ }^{20}$ Importantly, our study adds to this by demonstrating that changes in tissue inflammation occurs both close to, as well as distal to, direct surgical trauma.

This article is protected by copyright. All rights reserved. 
Measures of serum cytokines showed significant changes with surgical intervention. In particular, there was a significant intraoperative increase in serum IL-6, comparable to previous studies. ${ }^{20,21}$ Sakamoto et al demonstrated a peak in serum IL-6 $(224.0 \pm 66.6 \mathrm{pg} / \mathrm{ml})$ occurred on post-operative day 1 , dropping to baseline levels by Day $14 .^{20}$ Intraoperative levels were not reported. Our results showed comparable rises in IL-6, however our intraoperative data showed that the peak in IL-6 concentration occurred intra-operatively, with a progressive decrease in IL-6 over seven post-operative days.

There is mounting evidence that implicates these inflammatory cytokines in tumour dissemination and progression. The correlation of cytokines, particularly IL-6, with postoperative outcomes in gastrectomy patients, and in other cancer resection has been suggested previously. ${ }^{9,11}$ The ability of IL- $1^{2}$ and TNF- \pm to promote the adhesion and implantation of human gastric carcinoma cells has been shown to be dose-dependent and inhibited by anti-IL$1^{2}$ and anti-TNF-.$\pm{ }^{11}$ Our data have shown a profound local adipose tissue up-regulation of IL- 6 and IL- $1^{2}$ mRNA expression and an unchanged but elevated serum TNF- \pm concentration during surgery. This could be a possible mechanism that facilitates transcoelomic tumour implantation.

Previous studies have characterised immunological disturbances following major surgery, with impaired cell-mediated immunity. ${ }^{2,3}$ Conflicting studies show increases ${ }^{22}$ and decreases $^{23}$ in lymphoid cell populations. We found evidence of impairment in the systemic cellular immune response, with significantly decreased concentrations of T-cells and dendritic cells, despite elevated local and systemic cytokine production. It is well established that these cells play vital roles in tumour surveillance and control. ${ }^{5,6,24}$ Modulation of T-cell 
and antigen presenting cell activity in animal models, and study of immunosuppressed patients, have shown increased tumour incidence and spread. ${ }^{5,24}$ The alteration in immune profile observed in our study may affect cancer immunosurveillance, potentially enabling progression or recurrence during the peri-operative period. However, more work needs to be done to establish the clinical impact of the observed changes in cell populations suggested by these data.

There are some limitations that warrant discussion. Firstly, our study is limited by its exploratory nature. However, we were able to obtain a detailed picture of the inflammatory response to radical OG cancer resection, by taking repeated measurements, and measuring a range of biomarkers. Secondly, whilst we have measured serum cytokine levels to reflect post-operative trends in inflammation, the application and interpretation in a clinical setting remains uncertain. Various factors are known to influence cytokines such as IL-6, including operative location, surgical time, blood loss and other systemic inflammatory condition. ${ }^{20,25,26}$ Furthermore, differences in basic science laboratory protocols can introduce variability unrelated to disease or surgical factors. These factors likely contribute the variability in IL-6 in the literature and create difficulty in direct translation to clinical practice. Further standardisation and validation of cytokine levels would be required before they could be used in a clinical setting to predict disease risk or prognosis. Finally, we limited patient recruitment to those undergoing open surgery to minimise heterogeneity in this exploratory study. Previous studies have explored the effects of laparoscopic versus open surgery on the systemic inflammatory response. ${ }^{27}$ Further research focusing on the effects of minimally 
invasive surgery on the peritoneal inflammatory profile and a comparison with open surgery would be an interesting future endeavour.

Future directions should focus on determining if these measures of inflammation are genuinely responsible for tumour implantation and dissemination. A number of potential targets relating to the up-regulation of inflammation have been identified. Ultimately, this may inform peri-operative targeting of specific immune responses that may improve patient outcomes by alleviating theoretical surgically accelerated tumourigenesis and dissemination.

We conclude with our principal finding that radical surgery for OG cancer upregulates the expression of pro-tumourigenic cytokines in the peritoneum and systemically. This offers two potential pathways that may facilitate tumour progression - local and systemic inflammation promoting peritoneal adherence and implantation, and secondary suppression of systemic immunosurveillance. This may be a mechanism that contributes to worse prognosis, and could potentially be explored as a peri-operative pharmacological target to ameliorate the contribution of surgical stress on tumour progression. 


\section{References}

[1] Songun I, Putter H, Kranenbarg EM-K, Sasako M, van de Velde CJH. Surgical treatment of gastric cancer: 15-year follow-up results of the randomsed nationwide Dutch D1D2 trial. Lancet Oncol. 2010;11:439-49.

[2] Hensler T, Hecker H, Heeg K, et al. Distinct mechanisms of immunosuppression as a consequence of major surgery. Infect immun. 1997;65:2283-91.

[3] Ni Choileain N, Redmond HP. Cell response to surgery. Arch Surg. 2006;141:1132-40.

[4] Wang L, Shen Y. Imbalance of circulating T-lymphocyte subpopulation in gastric cancer patients correlated with performance status. Clin Lab. 2013;59:429-33.

[5] Zou W. Immunosuppressive networks in the tumour environment and their therapeutic relevance. Nat Rev Cancer. 2005;5:263-74.

[6] Munn LL. Cancer and inflammation [Overview]. Wiley Interdiscip Rev Sys Biol Med. 2017;9:e1370.

[7] Kundu JK, Surh Y-J. Inflammation: Gearing the journey to cancer. Mutat Res Rev Mutat Res.. 2008;659:15-30.

[8] Kinoshita H, Hirata Y, Nakagawa H, et al. Interleukin-6 mediates epithelial-stromal interactions and promotes gastric tumorigenesis. PloS One. 2013;8:e60914.

[9] van Grevenstein WM, Hofland LJ, Jeekel J, van Eijck CH. The expression of adhesion molecules and the influence of inflammatory cytokines on the adhesion of human pancreatic carcinoma cells to mesothelial monolayers. Pancreas. 2006; 32:396-402.

[10] ten Kate M, Hofland LJ, van Grevenstein WM, van Koetsveld PV, Jeekel J, van Eijck CH. Influence of proinflammatory cytokines on the adhesion of human colon carcinoma cells to lung microvascular endothelium. Int J Cancer. 2004;112:943-50.

This article is protected by copyright. All rights reserved. 
[11] Yu G, Tang B, Yu PW, Peng ZH, Qian F, Sun G. Systemic and peritoneal inflammatory response after laparoscopic-assisted gastrectomy and the effect of inflammatory cytokines on adhesion of gastric cancer cells to peritoneal mesothelial cells. Surg Endosc. 2010;24:2860-70. [12] Apte RN, Voronov E. Is interleukin-1 a good or bad 'guy' in tumor immunobiology and immunotherapy? Immunol Rev. 2008;222:222-41.

[13] Le Bitoux MA, Stamenkovic I. Tumor-host interactions: the role of inflammation. Histochem Cell Biol. 2008;130:1079-90.

[14] Balkwill F. TNF-alpha in promotion and progression of cancer. Cancer Metastasis Rev. 2006;25:409-16.

[15] O'Riordan JM, Abdel-latif MM, Ravi N, et al. Proinflammatory cytokine and nuclear factor kappa-B expression along the inflammation-metaplasia-dysplasia-adenocarcinoma sequence in the esophagus. Am J Gastroenterol. 2005;100:1257-64.

[16] Carmi Y, Voronov E, Dotan S, et al. The role of macrophage-derived IL-1 in induction and maintenance of angiogenesis. J Immunol. 2009;183:4705-14.

[17] Cichowitz A, Burton P, Brown W, et al. Ex vivo dissection increases lymph node yield in oesophagogastric cancer. ANZ J Surg. 2013; 85:80-4.

[18] van Grevenstein WM, Hofland LJ, van Rossen ME, van Koetsveld PM, Jeekel J, van Eijck $\mathrm{CH}$. Inflammatory cytokines stimulate the adhesion of colon carcinoma cells to mesothelial monolayers. Dig Dis Sci. 2007;52:2775-83.

[19] Li M, Knight DA, Snyder LA, Smyth MJ, Stewart TJ. A role for CCL2 in both tumor progression and immunosurveillance. Oncoimmunology. 2013;2:e25474.

[20] Sakamoto K, Arakawa H, Mita S, et al. Elevation of circulating interleukin 6 after surgery: factors influencing the serum level. Cytokine. 1994;6:181-6. 
[21] Kikuchi K, Kurokawa H, Matsumoto F, et al. [Responses of cytokines, acute phase proteins, and polymorphonuclear cell elastase to surgical stress in the patients with esophageal cancer]. Rinsho byori. 1996;44:579-84.

[22] Wang Z, Si X, Xu A, et al. Activation of STAT3 in human gastric cancer cells via interleukin (IL)-6-type cytokine signaling correlates with clinical implications. PloS One. 2013;8:e75788.

[23] Yamaguchi Y, Hihara J, Hironaka K, et al. Postoperative immunosuppression cascade and immunotherapy using lymphokine-activated killer cells for patients with esophageal cancer: possible application for compensatory anti-inflammatory response syndrome. Oncol Rep. 2006;15:895-901.

[24] Swann JB, Smyth MJ. Immune surveillance of tumors. J Clin Invest. 2007;117:1137-46.

[25] Cruickshank AM, Fraser WD, Burns HJG, Van Damme J, Shenkin A. Response of interleukin-6 in patients undergoing elective surgery of varying severity. Clin Sci. 1990;79:161-5. [26] Murata A, Ogawa M, Yasuda T, et al. Serum interleukin 6, C-reactive protein and pancreatic secretory trypsin inhibitor (PSTI) as acute phase reactants after major thoraco-abdominal surgery. Immunol Invest. 1990;19:271-8.

[27] Pascual M, Alonso S, Pares D, et al. Randomized clinical trial comparing inflammatory and angiogenic response after open versus laparoscopic curative resection for colonic cancer. Br J Surg. 2010;98:50-9. 


\section{Figure legend}

\begin{tabular}{|c|c|}
\hline Figures & Caption \\
\hline Figure 1 & verview of tissue sample collection and biochemical analysis. \\
\hline Figure 2 & $\begin{array}{l}\text { mRNA expression of pro-inflammatory factors in peri-visceral adipose } \\
\text { tissue adjacent to and remote from the operative site. (A) interleukin-6 } \\
\text { (IL-6), (B) chemokine ligand-2 (CCL2), and(C) interleukin- }{ }^{2} \text { (IL-1²) } \\
\text { expression. A substantial increase in the expression of pro-inflammatory } \\
\text { cytokines was observed during surgery in visceral adipose tissue both } \\
\text { adjacent to and remote from the operative site. There was no statistically } \\
\text { significant difference in the magnitude of this inflammatory response at } \\
\text { the different sites. }\end{array}$ \\
\hline Figure 3 & $\begin{array}{l}\text { Intra-operative serum concentrations of myeloid and lymphoid cells. (A) } \\
\text { Total leukocytes, (B) Dendritic cells concentrations, (C) Neutrophils, } \\
\text { and (D) T-cells concentrations. A substantial change in the serum } \\
\text { concentrations of these cells were observed at the end of surgery from } \\
\text { baseline levels. }\end{array}$ \\
\hline Figure 4 & $\begin{array}{l}\text { Serum cytokine levels during surgery (shaded) and for six post-operative } \\
\text { days - (A) interleukin-6 (IL-6), (B) tumour necrosis factor- } \pm(\mathrm{TNF}- \pm) \text {, } \\
\left.\text { and (C) interleukin- }{ }^{2} \text { (IL- } 1^{2}\right) \text { concentration. Serum concentrations of } \\
\text { IL-6 were seen to increase intra-operatively, reaching a peak at the end } \\
\text { of surgery }\left(161.8 \mathrm{pg} / \mathrm{ml},{ }^{*} \mathrm{p}<0.05\right) \text { and subsequently decreasing to }\end{array}$ \\
\hline
\end{tabular}




\begin{tabular}{|l|l|}
\hline baseline levels at day six. TNF- \pm levels were elevated at baseline and \\
did not change significantly post-operatively. IL- ${ }^{2}$ levels had no \\
significant change in the intraoperative or post-operative period.
\end{tabular}

This article is protected by copyright. All rights reserved. 
Table 1. Pre-operation clinical data, intra-operative estimated surgical stress and post-operative histopathology and admission details.

\begin{tabular}{|c|c|}
\hline Variables & Study population, $n=9$ \\
\hline \multicolumn{2}{|l|}{ Demographics } \\
\hline Mean age \pm SEM & $67.1 \pm 2.1$ \\
\hline Sex ratio (male:female) & $5: 4$ \\
\hline \multicolumn{2}{|l|}{ Anatomical site } \\
\hline Oesophagogastric junction & $4(44.4 \%)$ \\
\hline Gastric & $5(55.6 \%)$ \\
\hline \multicolumn{2}{|l|}{ Stage } \\
\hline I & $1(11.2 \%)$ \\
\hline II & $4(44.4 \%)$ \\
\hline III & $4(44.4 \%)$ \\
\hline \multicolumn{2}{|l|}{ Operation performed } \\
\hline Subtotal gastrectomy & $3(33.3 \%)$ \\
\hline Total/extended gastrectomy & $3(33.3 \%)$ \\
\hline Ivor-Lewis oesophagectomy & $3(33.3 \%)$ \\
\hline \multicolumn{2}{|c|}{ Operative details (all procedures, $n=9$ ) } \\
\hline Total duration (minutes) & $155.2 \pm 16.4$ (range: $98-279)$ \\
\hline Estimated blood loss (mL) & $383.3 \pm 107.8$ \\
\hline Removed tissue (grams) & $736.3 \pm 159.3$ \\
\hline \multicolumn{2}{|l|}{ Histopathology } \\
\hline Total node yield & $29.1 \pm 4.9$ \\
\hline Patients with positive nodes & 4 \\
\hline \multicolumn{2}{|l|}{ Admission details } \\
\hline ICU admission & $4(44.4 \%)$ \\
\hline ICU length of stay (hours) & $3.4 \pm 0.8$ \\
\hline Hospital length of stay (days) & $13.4 \pm 2.4$ \\
\hline In hospital complications & $\begin{array}{l}1 \text { (minor wound infection, } \\
\text { Clavien Dindo Grade I) }\end{array}$ \\
\hline In hospital mortality & 0 \\
\hline 30-day mortality & 0 \\
\hline
\end{tabular}

Values are mean \pm standard error of the mean (SEM) or number (percentage of $n$ ) unless otherwise specified. SCC-squamous cell carcinoma; ICU-intensive care unit 
Specimen collection

Tissue type

Analysis

Cytokines

\section{Intra-operative}

1. baseline 2. $2 \mathrm{hrs}$ post incision 3. prior to closure

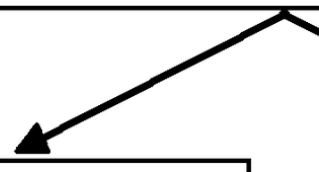

Adipose tissue

Adjacent and distant to tumor

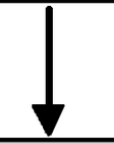

\begin{tabular}{|c|}
\hline Real time PCR \\
\hline mRNA \\
expression: \\
1. IL-6 \\
2. IL-1 $\beta$ \\
3. TNF- $\alpha$ \\
4. CCL2 \\
\hline
\end{tabular}

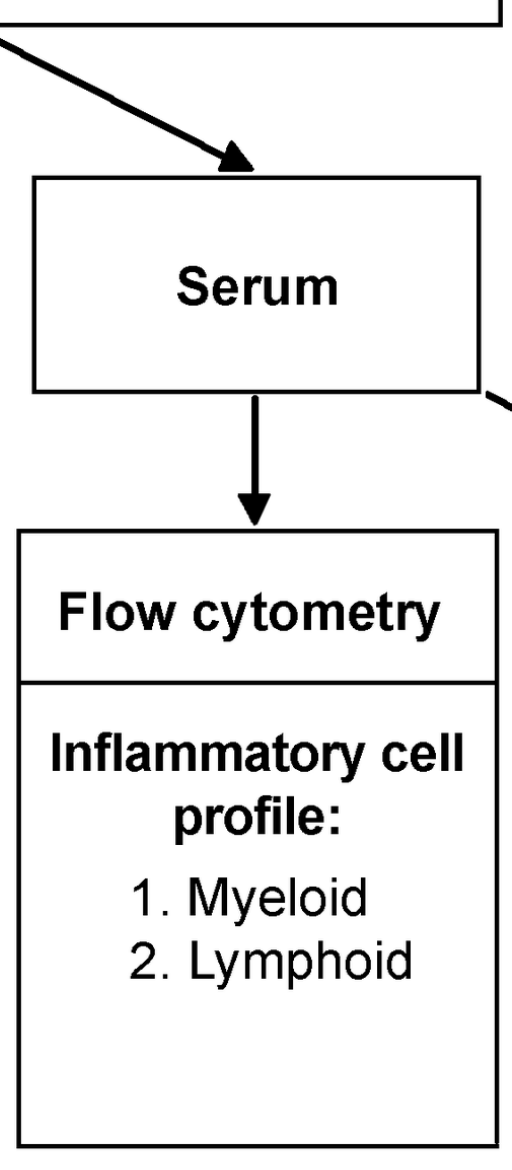

Figure 1.tif

\section{Post-operative}

daily for 7 days

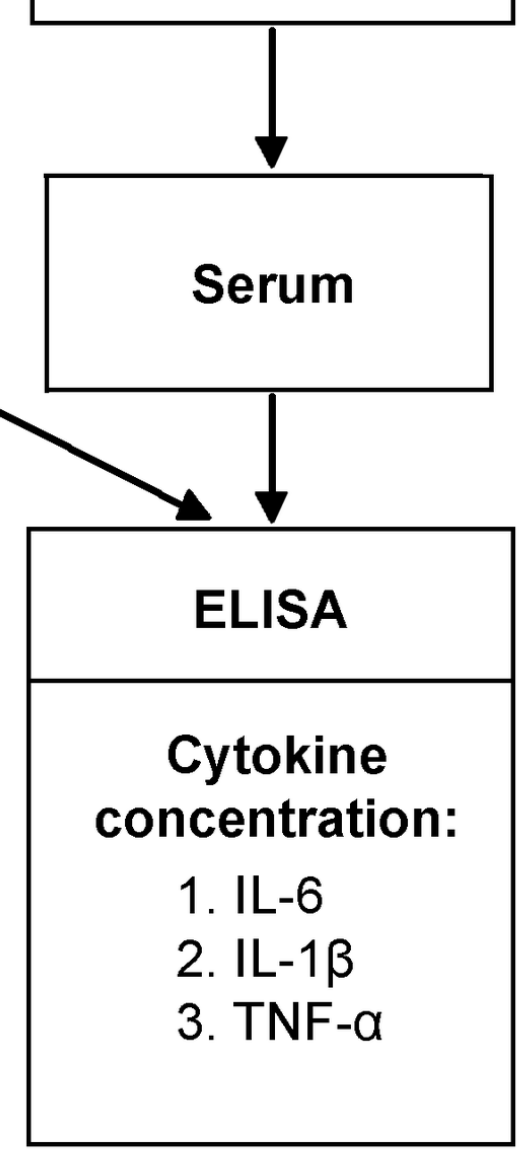




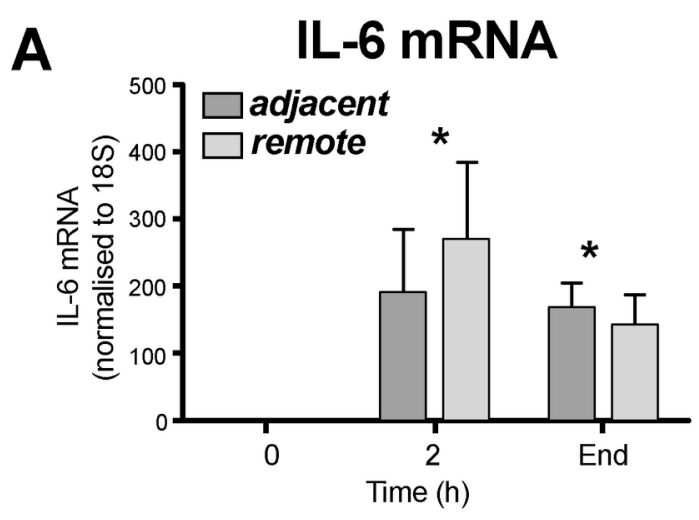

B
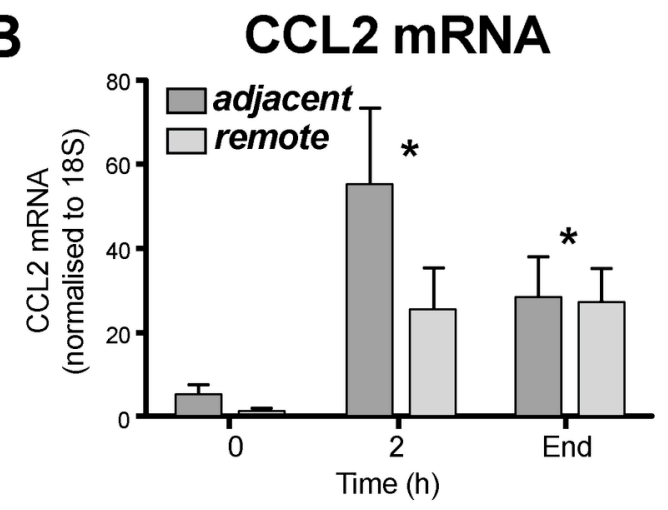

C

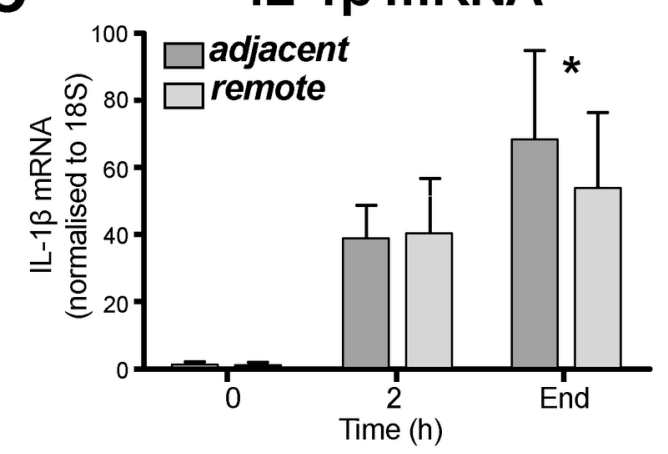

Figure 2.tif 

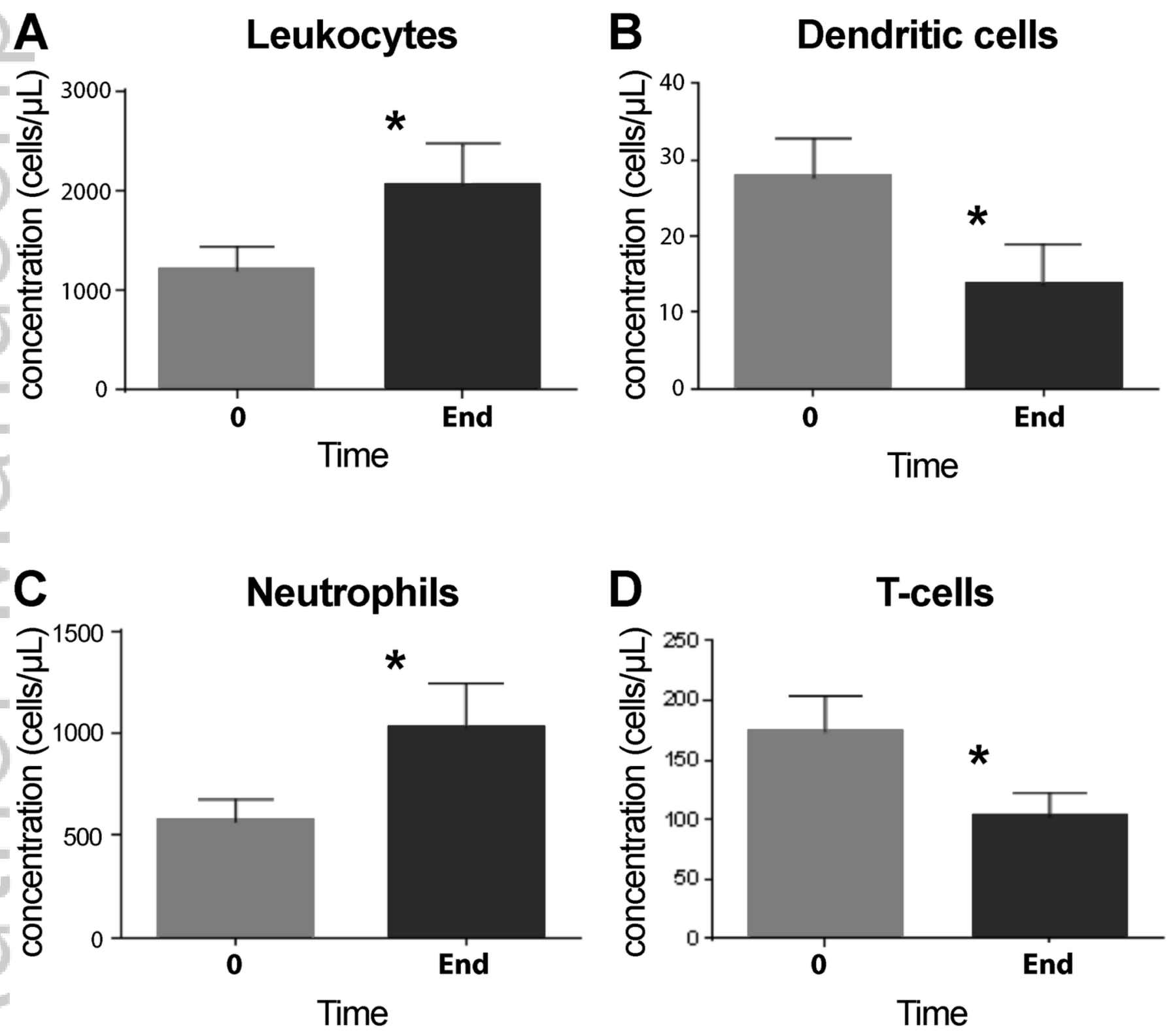

Figure 3.tif 
A

IL-6

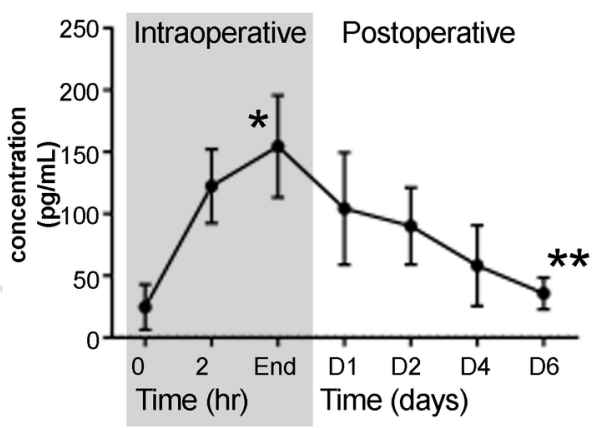

B

TNF- $\alpha$
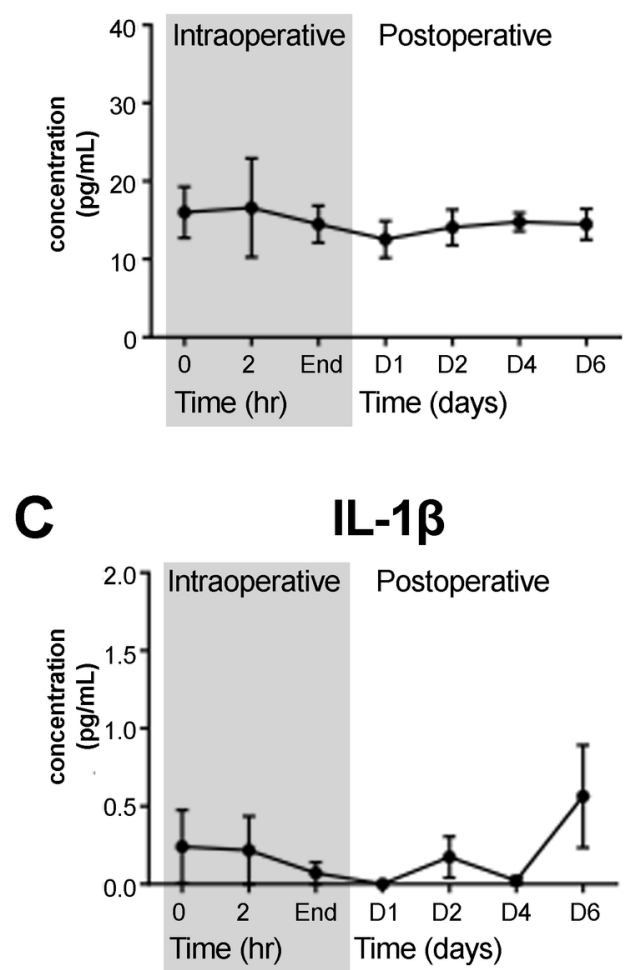

Figure 4.tif

This article is protected by copyright. All rights reserved. 


\section{University Library}

\section{- M M N E R VA A gateway to Melbourne's research publications}

Minerva Access is the Institutional Repository of The University of Melbourne

\section{Author/s:}

Long, AJ;Burton, PR;De Veer, MJ;Ooi, GJ;Laurie, CP;Nottle, PD;Watt, MJ;Brown, WA

Title:

Radical gastric cancer surgery results in widespread upregulation of pro-tumourigenic intraperitoneal cytokines.

\section{Date:}

2018-05

\section{Citation:}

Long, A. J., Burton, P. R., De Veer, M. J., Ooi, G. J., Laurie, C. P., Nottle, P. D., Watt, M. J. \& Brown, W. A. (2018). Radical gastric cancer surgery results in widespread upregulation of pro-tumourigenic intraperitoneal cytokines.. ANZ J Surg, 88 (5), pp.E370-E376. https:// doi.org/10.1111/ans.14267.

Persistent Link:

http://hdl.handle.net/11343/293944 